\title{
PENCERAHAN SEBAGAI KEBEBASAN RASIO DALAM PEMIKIRAN IMMANUEL KANT
}

\author{
Robby Habiba Abror \\ UIN Sunan Kalijaga Yogyakarta
}

\begin{abstract}
Abstrak: Tulisan ini mencoba mengeksplorasi pemikiran Immanuel Kant tentang Pencerahan. Pencerahan bagi Kant adalah pembebasan manusia dari ketidakdewasaan yang disebabkan oleh kesalahannya sendiri, karena tidak mampu menggunakan akal tanpa tuntunan orang lain. Konsepsi Kant tentang Pencerahan menjadi ciri khas filsafat Jerman membebaskan rasio manusia untuk berani berpikir dan melakukan perubahan yang signifikan bagi masyarakatnya. Pesan Kant yang tajam secara metafisik sesungguhnya dapat dimaknai lebih dalam tidak hanya mengukuhkan prinsip-prinsip dasar kebebasan rasio dan keberanian berpikir bagi manusia, tetapi juga secara tersirat menggugat otoritas keagamaan yang seringkali dalam sejarah berselingkuh dengan kekuasaan despotik dalam rangka memuluskan proyek-proyek pembangunan dan penindasan. Masyarakat harus didorong agar berani menggunakan rasionya sendiri dengan sepenuhnya, sebab dari sana bermuara kebebasan dan terbitnya kemandirian.
\end{abstract}

Kata Kunci: Pencerahan, Filsafat, Jerman, Kebebasan, Rasio

\section{A. Pendahuluan}

Membicarakan pencerahan (Enlightenment atau Aufklärung) tidak dapat dilepaskan dari peran sentral Rene Descartes (1596-1650), pendiri sekaligus sebagai bapak Filsafat Modern, yang berhasil memantik semangat ilmiah dan pentingnya filsafat kesadaran sebelum fisikawan Newton-ilmuwan yang juga menginspirasi Adam Smith dalam gerakan pencerahan Inggris yang dikenal dengan gagasan laissez faire dan the invisible hands (tangan-tangan yang tak tampak). Hidup sejaman dengan Bacon dan Galileo, Descartes dapat menyatukan metode dari berbagai usaha penyelidikan manusia, yakni langkahnya meletakkan pondasi metodis di ranah filsafat yang disebut "metode kesangsian" yakni bahwa baginya, menyangsikan berarti berpikir. Dalam karyanya Discourse on 
Method (1637), ia berusaha mengarahkan akal budi demi penemuan kebenaran secara sistematis dan dasar yang kokoh bagi realitas. Descartes menegaskan bahwa memiliki daya nalar yang baik tidaklah cukup sebab yang lebih penting adalah bagaimana menggunakannya dengan baik. Ia membangun pondasi ilmu dengan kepastian dan memungkinkan bagi penyatuan suatu pemikiran.

Kekuatan rasio manusia menduduki posisi penting dalam semangat zaman pencerahan ini, yakni upayanya dalam menggugat dominasi agama, pemikiran metafisis abad pertengahan dan kepercayaan pada takhayul. Dengan rasio, manusia diyakinkan dapat menggeser peran iman sehingga dapat melahirkan kebenaran otentik yang berujung pada hidup bahagiatidak heran jika proyek pencerahan ini identik dengan gerakan sekularisasi, kalaupun tetap ajeg dalam iman agama maka aspek rasional dan empiris harus lebih dominan. Satu syarat penting mewujudkan kebahagiaan dalam hidup ini, dalam pandangan Immanuel Kant (17241804) yaitu bahwa manusia harus menggunakan rasio dengan sungguhsungguh.

Pencerahan dalam praktiknya sebenarnya melanjutkan pandangan Renaisans yaitu pada keyakinan bahwa apa yang baik dan bernilai pada dirinya ada pada dunia alamiah ini sebagaimana optimisme dalam sains modern yang dirintis Isaac Newton (1643-1727). Ide pencerahan di Inggris ditandai oleh deisme, yaitu gerakan pemikiran abad ke-17 dan 18 yang berusaha menggeser peran wahyu dengan kekuatan rasio. Dari kata deusyang artinya dewa, deisme meyakini bahwa ada satu Tuhan pencipta alam ini dan Tuhan berlepas diri dari alam ciptaannya. Ini berbeda dengan ateisme yang menyangkal keberadaan Tuhan atau panteisme yang menyatukan Tuhan ke dalam alam. Di balik ide pencerahan Inggris, filsafat rasionalisme Prancis berkembang baik di sana.

Jika ide pencerahan di Inggris mengusung deisme dan mendesakralisasi agama, maka ide pencerahan di Prancis-yang juga terpengaruh oleh filsafat empirisme Inggris dan fisika Newton ${ }^{1}$

${ }^{1}$ Newton dipuja oleh kalangan penyair sebagai pembawa terang: "Nature and Nature's laws lay hid in night. God said, 'Let Newton be!' and all was light" (Pada mulanya alam dan hukumnya tersembunyi dalam kegelapan malam. Tuhan berkata, 'Jadilah Newton!', maka segala sesuatunya menjadi terang). S.P.L. Tjahjadi, Petualangan Intelektual: Konfrontasi dengan Para Filsuf dari Zaman Yunani higga Zaman Modern (Yogyakarta: Kanisius, 2004), hlm. 182. 
melakukan gerakan kritis yaitu profanisasi kehidupan juga dengan membongkar berbagai aspek teologis yang selama ini mendukung feodalisme di Eropa, sehingga peran ilmu-ilmu alam dianggap mampu menyejahterakan masyarakat melalui kemajuan ilmu pengetahuan dan teknologi. Lahirnya Revolusi Prancis pada $1789^{2}$ tidak dapat dilepaskan dari peran para filsuf Prancis seperti Montesquieu (1689-1755) yang dikenaldengan ide trias politica-nya, Rousseau (1712-1778) dengan kontrak sosialnya, dan Voltaire (1694-1778) sebagai juru bicara zaman pencerahan yang kerap mengkritisi dogma Gereja Roma dengan teriakannya yang terkenal: ecrasez l'infame (hancurkan yang sesat!).

Selanjutnya, ide pencerahan di Jerman juga diilhami oleh deisme Inggris yang konsisten memisahkan urusan wahyu dengan rasio. Muncul juga penggiat estetika dan sastrawan seperti Baumgarten (1714-1762) dan Goethe (1749-1832) yang menyemarakkan filsafat Jerman era itu sehingga ikut serta mewarnai pencerahan Jerman, kendatipun demikian kelak Immanuel Kantlah yang mendobrak pencerahan Jerman melalui pemikirannya yang khas tentang pencerahan dan menandai filsafat Jerman modern.

\section{B. Sekilas tentang Kehidupan dan Intelektualitas Immanuel Kant}

Immanuel Kant dilahirkan pada 22 April 1724 di Konigsberg, Prusia Timur. Sepanjang hidupnya, filsuf Jerman ini tidak pernah berpolitik praktis. Ia meninggal pada usia delapan puluh tahun di kota yang sama pada 12 Februari 1804. Kant dibesarkan dalam keluarga yang taat beragama. Ayahnya, seorang keturunan imigran Skotlandia, bekerja membuat pelana kuda, sedangkan ibunya seorang wanita Jerman yang alim dan cerdas. Keluarganya beragama Kristen yang taat, Kant seorang Lutheran yang saleh dengan hidup sederhana berdasarkan hukum-hukum

${ }^{2}$ Revolusi Prancis terjadi tak lepas dari serangkaian revolusi di Eropa juga keterkaitannya dengan revolusi Amerika. Revolusi Prancis disebabkan di antaranya oleh: kenaikan harga-harga yang tak terkendali, pemberontakan karena lapar, berkurangnya pendapatan Negara, dominasi kaum borjuis dan menguasai ekonomi dan merebut kekuasaan, kaum bangsawan memonopoli semua jabatan, belum lagi peran Prancis dalam menyokong urusan perang Maerika dengan keuangan yang tak terkontrol. Jacques Godechot. Revolusi di Dunia Barat (1770-1799), terj. Pusat Kebudayaan Prancis (Yogyakarta: UGM Press, 1989), hlm.ix dan 34-37. Lihat juga Karl Lowith, From Hegel to Nietzsche: The Revolution in Nineteenth-Century Thought (New York, Chicago dan San Fransisco: Holt, Rinehart dan Winston, 1965). 
moral dan mencintai fisika Newton. Kant mampu mendamaikan agama dan ilmu pengetahuan dalam dirinya. Bagi Kant, seseorang mesti membatasi pengetahuan untuk memberi ruang pada iman.

Kant kuliah teologi di Universitas Konigsberg pada 1740 dan dipengaruhi rasionalisme Christian Wolff. Saat studinya, ia mempelajari fisika mekanistik Newtonian, metafisika dan logika. Kecerdasannya tampak dalam penguasaannya terhadap semua ilmu pada waktu itu. Ia menulis karya pertamanya tentang fisika sejak berusia dua puluh tahun. Ia pernah gagal melamar jadi dosen sehingga enam tahun kemudian, ia harus bekerja sebagai tutor atau dosen privat bagi keluarga-keluarga bangsawan. Periode ini berlangsung selama lima belas tahun. Sebenarnya, Kant dekat dengan seluruh komunitas kota yang menyediakan kesempatan berlimpah untuk acara jalan-jalan. Perjalanan terjauhnya hanya ke kota Arnsdorf, 60 mil dari kota kelahirannya, tak pernah pergi jauh lebih dari itu. Kant lebih memilih membaca buku untuk menambah pengetahuan daripada jalanjalan. Kant dikenal di bangku kuliah sebagai mahasiswa berbakat alami, sering melontarkan anekdot dan uraian sastra yang memikat. Saat mengajar, ia mampu membahas semua topik yang ada dengan fasih: fisika Newton, undang-undang agraria, dan festival rakyat. Karya awal Kant cenderung pada ilmu-ilmu alam daripada filsafat. Ia berminat pada Geografi fisik dan fisika. Ia pernah menulis teori tentang gempa pasca gempa bumi Lisbon. Juga menulis risalah tentang angin, esai pendek yang menyoal apakah angin Barat di Eropa basah karena melintasi samudera Atlantik. $^{3}$

Kant pernah menolak saat dirinya diminta menjadi profesor sastra di Universitas Berlin dengan alasan tak mau keluar dari kota kelahirannya. Ia seumur hidupnya tidak pernah menikah, sosok yang dikenal jenius, puritan, rendah hati, tidak sombong, cerdas dan tertib. Ia setiap hari berjalan kaki keluar rumah, sehingga masyarakat dapat mencocokkan jamnya jika melihatnya. Kant selalu tepat waktu jika melewati suatu tempat, sehingga jalan yang sering dilaluinya dinamai "Jalan Filsuf", sepeninggalnya. Kita dapat mengenal gambaran lebih nyata tentang kepribadian Immanuel Kant dari Johann Gottfried Herder, seorang penulis Jerman, yaitu komentar murid abad ke-18 ini tentang guru filsafatnya.

3 Bertrand Russell,History of Western Philosophy and its Conection with Political and Social Circumstances from the Earliest Times to the Present Day (London: George Allen and UNWIN LTD, 1946), hlm.731-732. 
I have had the good fortune to know a philosopher. He was my teacher. In his prime he had the happy sprightliness of a youth; he continued to have it, I believe, even as a very old man. His broad forehead, built for thinking, was the seat of an imperturbable cheerfulness and joy. Speech, the richeset in thought, flowed from his lips. Playfulness, wit, and humor were at his command. His lectures were the most entertaining talks; his mind, which examined Leibniz, Wolff, Baumgarten, Crusius, and Hume, and investigated the laws of nature of Newton, Kepler, and the physicists, comprehended equally the newest works of Rousseau... and the latest discoveries in science. He weighed them all, and always came back to the unbiased knowledge of nature and to the moral worth of man. The history of men and peoples, natural history and science, mathematics and observation, were the sources from which he enlivened his lectures and conversation. He was indiferenct to nothing worth knowing. No cabal, no sect, no prejudice, no desire for fame could ever tempt him in the slightest away from broadening and illuminating the truth. He incited and gently forced others to think for themselves; despotism was foreign to his mind. This man, whom I name with the greatest gratitude and respect, was Immanuel Kant. ${ }^{4}$

(Saya memiliki keberuntungan yang baik bisa mengenal seorang filsuf. Ia adalah guru saya. Pada masa kejayaannya, ia memiliki kegembiraan masa muda yang bahagia, dan ia terus memilikinya, saya percaya, meski ia sudah menjadi pria yang sangat tua. Dahinya lebar, dibangun untuk berpikir, yang merupakan tempat kegembiraan dan kebahagiaan yang tidak bisa diganggu. Ucapannya, paling kaya dalam pemikiran, mengalir dari bibirnya. Gembira, cerdas, dan humor ada di tangannya. Kuliah-kuliahnya merupakan percakapan yang paling menghibur; pikirannya, yang mengamati pikiran Leibniz, Wolff, Baumgarten, Crusius, dan Hume, serta meneliti hukum-hukum alam Newton, Kepler, dan para fisikawan, juga memahami karya-karya terbaru Rousseau ... dan berbagai penemuan terakhir dalam ilmu pengetahuan. Ia menimbang semuanya, dan selalu muncul kembali dengan pengetahuan alam yang tidak dibiaskan dan nilai moral manusia. Sejarah manusia dan masyarakat, sejarah alam dan ilmu pengetahuan, matematika dan pengamatan, semuanya menjadi sumber untuk menghidupkan kuliah-kuliah dan percakapannya. Ia tidak membedabedakan pengetahuan yang tidak ada nilainya. Tidak ada sekutu atau persekongkolan, tidak ada sekte, tidak ada prejudis, tidak ada keinginan menjadi termasyhur yang pernah menggodanya sedikitpun dari memperluas dan menyinari kebenaran. Ia memacu dan dengan lembut memaksa orang lain untuk memikirkan diri mereka sendiri; despotisme tidak ada dalam pikirannya. Manusia ini, yang namanya

${ }^{4}$ Immanuel Kant, Foundations of the Metaphysics of Morals, terj. Lewis White Beck (Macmillan: Library of Liberal Arts, 1990), dari edisi Jerman, Grundlegung zur Metaphysik der Sitten (1785) \&Beantwortung der Frage: Was ist Aufklärung? (1784), hlm.xxvi. 
saya beri penghormatan dan rasa terima kasih saya yang paling besar, adalah Immanuel Kant.)

Pada 1756 Kant mengajar di Universitas Konigsberg termotivasi filsafat empirisme septisDavid Hume. Hume telah membangunkan Kant dari tidur dogmatisnya. Pada 1770 Kant dikukuhkan sebagai Guru Besar Logika dan Metafisika. Pada usia 60-an ia tinggalkan filsafat Wolff dan Leibniz yang pernah mempengaruhinya dengan kuat pada periode pra kritis, sehingga ia akui bahwa Hume telah mengganggu kamar tidur dogmatiknya dan memberi arah baru dalam penelitiannya di bidang filsafat spekulatif. Itulah periode kritis Kant yakni ketika ia mengembangkan sistem filsafatnya sendiri dalam karyanya Critique of Pure Reason (Kritik atas Rasio Murni). Pada 1781 Kant merilis filsafat barunya yaitu "filsafat kritis", "kritisisme" atau "kritisisme transendental". Di usianya yang ke delapan puluh tahun, Kant meninggal dunia. Terpahat tulisan di batu nisannya: "langit berbintang di atasku, dan hukum-hukum moral di hatiku" - menggambarkan ketekunannya pada fisika dan etika, ${ }^{5}$ yaitu pada dua prinsip hidupnya: "isilah pikiran dengan pengagungan yang selalu baru dan semakin bertambah dan tenanglah saat merenungkannya!"

Perseteruan dua aliran besar filsafat abad ke-18, yaitu antara Rasionalisme dan Empirisme, dapat diatasi oleh Kant. Bagi kaum rasionalis bahwa hanya rasio saja yang dapat memahami dunia tanpa perlu bantuan indera, sedangkan bagi kaum empiris tetap yakin bahwa semua pengetahuan harus berdasarkan pengalaman. Masing-masing memiliki kelemahan, di satu sisi pengetahuan yang diperoleh melalui rasio murni mungkin memang pasti, tetapi sedikit saja yang dapat menjelaskan cara dunia eksis. Di sisi lain, pengetahuan empiris memang dapat membahas banyak hal tentang dunia, tetapi harus mengorbankan kepastian jawabannya. Terobosan Kant bukan jalan pintas revolusi dalam filsafat. Saat para filsuf masih sibuk dengan masalah objek vis a vis pemahaman kita tentang objek, tindakan mendesak untuk mendamaikan keduanya disadari Kant. Bagi Kant, posisi Metafisika memfilsafatkan hakikat realitas telah bergerak maju di jalan yang sama sekali menyimpang, sehingga Hume menyerang dari sini. Bagi Hume, pengetahuan tentang

5 F. Budi Hardiman, Filsafat Modern: Dari Machiavelli sampai Nietzsche (Jakarta: Gramedia, 2004), hlm. 132. 
dunia yang dapat diindera tidak pernah dapat diperoleh kecuali hanya dengan indera. ${ }^{6}$

Pada periode kritis, gagasan Kant sebenarnya untuk menjawab tiga persoalan penting. Karyanya Critique of Pure Reason (1781) (Kritik atas Rasio Murni) untuk menjawab tentang apa yang dapat saya ketahui? (What can I know?), Critique of Practical Reason (1788) (Kritik atas Rasio Praktis) menjawab tentang apa yang seharusnya saya lakukan (What ought I to do?), Critique of Judgement (1790) (Kritik atas Daya Pertimbangan) untuk menjawab apa yang bisa saya harapkan (What may I hope?). ${ }^{7}$ Dengan tiga kritiknya itu, Kant ingin memeriksa kesahihan pengetahuan secara kritis, tidak dengan pengujian empiris, tapi dengan asas-asas a priori dalam diri subjek. Karena filsafatnya disebut transendentalisme, sebab iaingin mencari asas-asas a priori dalam rasio yang berkaitan dengan objek-objek dunia luar, yaitu tentang "syarat-syarat kemungkinan" dari pengetahuan. Peneltian disebut transendental jikafokus pada segala kondisi murni dalam diri subjek pengetahuan. Akhirnya, Kant dapat mensintesiskan rasionalisme yang mementingkan pengetahuan $a$ priori dengan empirisme yang mementingkan pengetahuan a posteriori. $^{8}$ Bagi Kant, pengetahuan merupakan hasil sintesis dari unsur-unsur a priori dan a posteriori-kedua istilah teknis yang dipinjam Kant dari Gottfried Wilhelm Leibniz.

Filsafatnya dikenal sebagai kritisisme yang berseberangan dengan dogmatisme. Jika dogmatisme menerima kemampuan rasio tanpa menguji batas-batasnya, maka kritisisme harus menyelidiki kemampuan dan batasbatas rasio sebelum memulai penyelidikan. Bagi Kant, kritisisme harus menyelidiki syarat-syarat kemungkinan bagi pengetahuan. Filsuf dogmatis seperti Wolff yang pernah mempengaruhinya, bermetafisika tanpa melakukan uji kesahihan metafisika. Bagi Kant, kritik sebagai alat untuk menguji kesahihan. Dalam proses pengujian, berbagai klaim pengetahuan diperiksa dengan kritis untuk mendapatkan pengetahuan sesuai prosedur yang benar.

\footnotetext{
${ }^{6}$ Nicholas Fearn. Zeno and the Tortoise: How to Think Like a Philosopher (New York: Grove Press, 2001), hlm. 103-106.

${ }^{7}$ Jon Simons, From Kant to Levi-Strauss: The Background to Contemporary Critical Theory (Edinburgh: Edinburgh University Press, 2002), hlm. 19.

8 Robert Paul Wolff, Kant: A Collection of Critical Essays (London dan Melbourne: Macmillan, 1968), hlm. 28-29.
} 
Selain tiga kritiknya, Kant juga menulis beberapa karya lainnya, di antaranya yaitu: Prolegomena to any Future Metaphysics (1783), Idea for a Universal History (1784), Foundation of the Metaphysics of Morals (1785), Metaphysical Foundations of Natural Science (1786), Religion within the Boundaries of Reason Alone (1793), Theory and Practice (1793), Perpetual Peace (1795), Metaphysics of Ethics, dua volume (1797), Anthropology from a Pragmatic Point of View (1798), dan The Strife of the Faculties (1798).

\section{Diskursus Kebebasan Rasio dalam Pencerahan}

Immanuel Kant menulis Was ist Aufklärung? (Apa itu Pencerahan?) diKönigsberg pada 30 September 1784. Kata-kata Kant yang paling terkenal ialah tentang makna Pencerahan (Enlightenment atau Aufklärung) yang dalam pandangannya berarti pembebasan manusia dari ketidakdewasaan yang disebabkan oleh kesalahannya sendiri, karena tidak mampu menggunakan akal tanpa tuntunan orang lain. Yang dimaksud Kant dengan What is Enlightenment? tergambar jelas dalam uraiannya yang sangat tenang dan tajam.

Pencerahan adalah pembebasan manusia dari perlindungan yang mengungkung diri. Perlindungan adalah ketidakmampuan manusia untuk menggunakan pengertiannya tanpa pengarahan dari orang lain. Mengungkung diri adalah perlindungan ini bila penyebabnya terletak bukan pada hilangnya rasio, melainkan terletak pada hilangnya ketetapan hati dan keberanian untuk menggunakannya tanpa pengarahan dari orang lain. Sapere aude!"Beranilah menggunakan rasiomu sendiri!"-inilah semboyan bagi pencerahan.

Kemalasan dan kepengecutan adalah alasan mengapa sebegitu banyak umat manusia, karena kodratnya yang telah lama melepaskan diri mereka dari pengarahan yang berasal dari luar (naturaliter maiorennes), sekalipun demikian tetap berada dalam perlindungan di sepanjang hidupnya, dan mengapa begitu mudah bagi orang lain untuk mengangkat diri mereka menjadi penjaga. Hal itu begitu mudah bukan karena usia. Jika saya memiliki buku yang mengerti aku, seorang pastor yang memiliki hati nurani untukku, seorang dokter yang menentukan dietku, dan seterusnya, aku tidak perlu mengkhawatirkan diriku sendiri. Aku tidak perlu berpikir, jika aku dapat membayar-orang lain akan siap melakukan pekerjaan untukku. ${ }^{9}$

\footnotetext{
${ }^{9}$ Immanuel Kant, Foundations of the Metaphysics of Morals, hlm. 83.
} 
Kant melihat bahwa penghalang bagi keberanian menggunakan rasio adalah ancaman nyata yang diciptakan oleh sikap malas dan pengecut. Sebaliknya jika seseorang berkompeten dalam suatu pekerjaan, ia dianggap berbahaya dan hanya akan mendapatkan kesulitan. Tapi Kant mengingatkan agar manusia berani dan bebas menggunakan rasio untuk mengatasi setiap ancaman dan bahaya ini. Seseorang harus terus belajar berjalan sendiri bahkan pun jika berkali-kali harus jatuh bangun, ia tetap harus melanjutkan upayanya tanpa rasa takut sedikit pun.

Perlindungan kekuasaan terhadap seseorang yang telah dijinakkan akalnya, akan membuatnya sulit berpikiran bebas dan tidak akan dibiarkan bebas berusaha menggunakan rasionya. Tetapi percayalah, bahwa kant tetap berharap bahwa kendatipun hanya sedikit orang mau menggunakan rasionya dengan berani dengan usaha pikirannya sendiri, maka sesungguhnya ia dapat dianggap telah berhasil dalam membebaskan diri mereka sendiri dari ketidakberdayaan dan bukti bagi keteguhan moral.

Dan ketahuilah bahwa masyarakat akan mendukungnya atas usahanya untuk membebaskan diri dari perlindungan semu, sebentuk pengkhianatan atas kebebasan rasio. Kant meyakinkan bahwa pencerahan pasti banyak pengikutnya dalam masyarakat. Sebab jika mereka mengetahui, bahwa dengan pikiran merdeka akan membebaskan mereka dari kebodohan, kemalasan dan kepengecutan di hadapan kekuasaan represif. Rakyat akan mendukung gerakan pencerahan ini, meskipun akan ada tantangan besar dari pemimpin yang zalim, yang senantiasa menaruh rasa curiga, menindas dan membalas dendam pada setiap upaya pembangkangan.

Tetapi, karena yang dibutuhkan pencerahan itu tidak lain adalah kebebasan, dan sebenarnya yang paling tidak berbahaya di antara semua hal yang dengan itu istilah ini dapat diterapkan dengan tepat. Ada kebebasan agar publik mau menggunakan rasionya sendiri untuk setiap hal. Namun aku dengar pada setiap sudut. "Jangan berdebat!" Kata opsir: "Jangan berdebat, tetapi berlatihlah!" Pemungut pajak: "Jangan berdebat, tetapi bayarlah!” Klerek: "Jangan berdebat, tetapi percayalah!” Hanya satu pangeran di dunia yang berkata, "Berdebatlah sejauh kamu mau, dan berdebatlah tentang apa yang kamu mau, namun patuhlah!" Di mana saja ada pembatasan atas kebebasan.

Pembatasan yang manakah yang menjadi kendala bagi pencerahan, dan yang tidak dapat menjadi kendala melainkan justru 
menjadi pendorong pencerahan? Aku jawab: Pemakaian publik atas rasio manusia harus senantiasa bebas, dan hanya itu yang dapat melahirkan pencerahan di antara manusia. Pemakaian rasio individu, di lain pihak, mungkin secara sangat sempit dibatasi tanpa secara khusus menghalangi kemajuan pencerahan. Melalui pemakaian publik rasio manusia, saya memahami pemakaian itulah yang membuat seseorang sebagai seorang sarjana di hadapan publik yang membacanya. Pemakaian individu, saya menyebut orang yang mungkin menggunakannya di dalam pos atau kantor sipil yang dipercayakan kepadanya. Banyak urusan yang dijalankan demi kepentingan masyarakat memerlukan mekanisme tertentu yang dengan itu para anggota masyarakat secara pasif mereka harus memerintah diri mereka sendiri dengan suara bulat yang artifisial, sehingga pemerintah mungkin mengarahkan mereka untuk tujuan publik, atau setidaknya mencegah mereka untuk menghancurkan tujuan tersebut. Argumen ini tentunya tidak diikuti-orang harus patuh. Namun sejauh sebagai bagian dari mekanisme yang mempertimbangkan dirinya sendiri yang sekaligus sebagai anggota dari seluruh masyarakat atau masyarakat warga dunia, dan dengan demikian dalam berperan sebagai sarjana yang menegur publik (dalam arti yang tepat dari kata tersebut) melalui tulisannya, tentunya dia dapat berdebat dengan tanpa merusak urusan yang menjadi bagian tanggung jawabnya sebagai anggota pasif. Dengan demikian akan terjadi kehancuran bagi opsir yang melayani dengan berdalih tentang kecocokan atau pemakaian perintah yang diberikan kepadanya oleh atasannya; dia harus patuh. Namun hak untuk membuat pernyataan yang salah dalam dinas kemiliteran dan untuk menempatkannya di hadapan publik karena pertimbangan tidak pantas, menolaknya sebagai sarjana. Warga negara tidak dapat menolak untuk membayar pajak yang dibebankan kepadanya; sebenarnya, keluhan yang kurang ajar pada orang yang menarik pajak padanya dapat dihukum sebagai skandal (karena hal itu dapat menyebabkan pembangkangan umum). Namun orang yang sama tidak dapat berbuat melawan kewajibannya sebagai seorang warga negara, sebagai seorang sarjana, ketika dia secara publik mengungkapkan pemikirannya secara tidak pas atau bahkan tidak adil tentang penarik pajak ini. ${ }^{10}$

Bagi Kant, pencerahan adalah kebebasan dan dengannya masyarakat harus terus didorong untuk menggunakan kebebasan rasio mereka baik dalam tradisi berdebat maupun keberanian mengemukakan pendapat, meskipun selalu ada ongkos mahal yang harus dibayar yaitu upaya pembatasan bagi setiap kebebasan. Pembatasan itu dapat saja digelar oleh kesatuan militer atas instruksi penguasa atau bahkan oleh seorang rohaniawan atau agamawan yang gagal memahami spirit

${ }^{10}$ Immanuel Kant, Foundations of the Metaphysics of Morals, hlm. 84-85. 
terdalam kitab sucinya. Agamawan yang terbiasa berkhutbah belum tentu berhasil dalam berkomunikasi dengan jamaahnya, salah memahami simbol-simbol sosial keagamaan, disebabkan hilangnya kecermatan dan pemikiran terbuka terhadap kebebasan rasio masyarakatnya. Pembatasan atas kebebasan tidak lain hanya akan melahirkan kontradiksi antara apa yang diyakini dengan inti ajaran agama. Jika ia menyadari sesungguhnya sikap membatasi orang lain sesungguhnya akan membuat dirinya sendiri tidak bebas karena ia menciptakan aturan pembatasan buat orang lain.

Setiap upaya pembatasan atas kebebasan, meskipun tindakan itu dilakukan karena mendapatkan perlindungan dari penguasa dan militer, tidak akan abadi. Masyarakat tidak akan membiarkan hal itu terjadi terlalu lama, sebab tindakan tersebut merupakan bentuk kejahatan melawan kodrat manusia, bahwa manusia ingin hidup bebas dan punya kebebasan rasio.

Bangsa mana pun tidak akan memilih patuh pada tindakan pembatasan dan tekanan. Membiarkan batu sandungan ini terus berlangsung hanya akan menambah beban berat bagi bangsa yang ingin maju dan bebas. Dampak dari tindakan pembatasan itu terletak pada ancaman disintegrasi salah satunya yang paling dikhawatirkan Kant adalah disharmoni antar umat beragama. Kant yakin bahwa kerukunan beragama akan terwujud menjadi lebih baik dengan melibatkan setiap warga Negara dalam menggunakan kebebasan rasio dan kebebasan berpendapat. Jangan pernah menyia-nyiakan waktu dan kesempatan untuk kemajuan umat manusia kea rah yang lebih baik dengan menunda-nunda pencerahan dan melanggar hak asasi masyarakat (HAM).

Jika kita ditanya, "Apakah kita sekarang hidup di zaman yang tercerahi?", jawabnya, "Tidak," tetapi kita hidup di zaman pencerahan. Karena sesuatu yang terjadi sekarang, banyak yang hilang yang mencegah manusia untuk dapat, atau dengan mudah menjadi, mampu dengan benar mengunakan rasio mereka sendiri dalam kaitannya dengan masalah keagamaan dengan jaminan dan bebas dari pengarahan yang berasal dari luar. Namun, di lain pihak, kita memiliki indikasi yang jelas bahwa bidang yang kini terbuka ketika manusia mungkin secara bebas mempersoalkan masalah ini dan bahwa kendala bagi pencerahan umum atau pelepasan dari perlindungan yang mengungkung diri secara berangsur-angsur berkurang. Dalam kaitan ini, inilah zaman pencerahan, atau abad Frederick.

Seorang pangeran yang tidak merasa dirinya tidak berharga mengatakan bahwa adalah kewajibannya untuk tidak memerintahkan 
apa pun kepada orang berkaitan dengan masalah keagamaan namun memberi mereka kebebasan penuh seraya menjunjung tinggi toleransi, dirinya sendiri tercerahi dan berhak mendapatkan penghargaan yang tulus oleh dunia dan anak cucunya sebagai yang pertama, setidaknya dari sisi pemerintah, yang telah melepaskan ras manusia dari perlindungannya dan membiarkan setiap orang bebas untuk menggunakan rasionya berkaitan dengan masalah hati nurani. Di bawah dia para rohaniwan yang mulia diizinkan, dalam perannya sebagai sarjana dan tanpa melanggar kewajiban resminya, secara bebas memberi hak kepada publik untuk menguji pertimbangan dan pandangan mereka yang di sana sini berbeda dengan simbol yang telah mapan. Dan bahkan kebebasan yang lebih besar dinikmati oleh orang yang dibatasi bukan karena kewajiban resmi. Semangat kebebasan ini menyebar melampaui bumi ini, sekali pun untuk itu harus berjuang dengan kendala yang berasal dari luar yang ditimbulkan oleh pemerintah yang tidak memahami kepentingannya sendiri. Untuk contoh guna memberikan bukti bagi pemerintahan tersebut bahwa di dalam kebebasan di sana tidak sedikit pun ada penyebab untuk memperhatikan kedamaian publik dan stabilitas masyarakat. Orang bekerja sendiri secara berangsur-angsur karena barbaritas jika hanya kelicikan yang disengaja tidak dibuat untuk menguasainya.

Saya telah menempatkan inti pokok pencerahan-pelepasan manusia dari perlindungan yang mengungkung diri-terutama dalam kaitannya dengan agama karena penguasa kita tidak memiliki kepentingan di dalam bermain sebagai penjaga dalam kaitannya dengan seni dan ilmu dan juga karena ketidakmatangan beragama bukan hanya satu-satunya yang paling merugikan melainkan juga yang paling merosotkan semua hal. Namun cara berpikir kepala negara yang mendukung pencerahan keagamaan melangkah lebih jauh, dan melihat bahwa tidak ada bahaya bagi kekuasannya dengan mengizinkan warga negara untuk menggunakan rasio mereka dan untuk menerbitkan pikiran mereka dengan formulasi yang lebih baik legislasinya dan bahkan mereka boleh mengkritik secara terbuka atas undang-undang yang telah dibuat. Berkaitan dengan hal ini kita memiliki contoh yang jelas ketika tidak ada raja yang lebih tinggi daripada dia, raja yang kita hormati.

Tetapi, hanya dia, dirinya yang tercerahi, tidak takut akan bayangan, dan yang memiliki banyak tentara yang berdisiplin baik untuk menjamin perda-maian publik, dapat mengatakan: "Berdebatlah sesuai dengan kemauanmu, dan tentang apa yang kamu mau, hanya patuhlah!" Sebuah republik tidak berani berkata demikian. Di sini ditunjukkan kecenderungan yang aneh dan tidak diharapkan dalam masalah yang berhubungan dengan manusia yang hampir-hampir menyangkut semua hal, yang terlihat sangat besar, 
adalah paradoks. Tingkat kebebasan sipil yang lebih besar tampak menguntungkan bagi kebebasan jiwa bangsa, dan malahan hal itu menempatkan batas yang tidak dapat dihindari di atasnya; tingkat kebebasan sipil yang lebih rendah, sebaliknya, membe-ri jiwa ruang untuk setiap orang untuk mengembangkan dirinya hingga kemampuannya yang penuh. Sebagaimana alam telah melepaskan cangkang keras biji yang dia pelihara dengan lembutkecenderungan dan keasyikan untuk berpikir bebas-hal ini secara berangsur-angsur bekerja kembali pada karakter bangsa, yang dengan begitu melangkah bijaksana menjadi mampu untuk mengatur kebebasan; akhirnya, hal tersebut berpengaruh pada prinsip pemerintahan, yang menguntungkan guna memperlakukan manusia, yang kini lebih dari sekedar mesin, sesuai dengan martabat mereka. ${ }^{11}$

Pesan-pesan moral Pencerahan Kant menggugah para filsuf sesudahnya dan merupakan gagasan cemerlang bagi filsafat Jerman. Setidaknya saya mencatat dua belas pesan penting dan berkorelasi secara sosial kegamaan dan politik yang dapat dipetik dari Pencerahan Kant, di antaranya yaitu: Pertama, ini sesungguhnya pesan penting dari Pencerahan Jerman, sebentuk kebijaksanaan dari etika individu, yakni bahwa Kant mengingatkan kita akan pentingnya membebaskan manusia dari belenggu kebodohan yang selama ini didorong oleh kelemahannya sendiri yang tak mampu menggerakkan potensi kreatifnya yang telah dianugerahkan Tuhan kepada dirinya yaitu, keberanian berpikir yang terbebas dari bayang-bayang dan ketergantungan terhadap orang lain.

Kedua, Kant membenci sikap pengecut dan malas yang melanda sebagian besar umat manusia. Kesuksesan yang diraih atas relasi yang tidak transparan dan disebabkan korupsi, kolusi dan nepotisme, dan bukan atas jerih payah sendiri dengan kejujuran dan komitmen untuk memberikan dengan tulus apapun yang terbaik untuk sebuah amanah, maka ia tidak layak mengemban amanah itu. Untuk semua keinginan, hasrat dan nafsunya, semuanya bisa dibayar, dan itu watak perusak yang harus dihindari.

Ketiga, Kant mendorong pentingnya kemandirian. Kebanyakan orang-orang yang berkompeten dan jujur justru dianggap ancaman bagi suatu departemen atau pemerintahan. Jika pun bisa sebaiknya orang itu disingkirkan cepat-cepat. Tapi bagi Kant, kemandirian mutlak bagi seseorang yang ingin melepaskan dirinya dari belenggu dan kekangan

\footnotetext{
${ }^{11}$ Immanuel Kant, Foundations of the Metaphysics of Morals, hlm. 83-90.
} 
orang-orang yang bodoh dan penjilat. Jangan takut berbuat baik dan terus berusaha!

Keempat, Kant percaya bahwa usaha yang didasarkan atas pikiran kita sendiri dapat melepaskan diri kita dari ketidakberdayaan yang disebabkan oleh ketergantungan pada orang lain, atasan atau penguasa.

Kelima, Kant menegaskan pentingnya kebebasan sebagai prasyarat pencerahan. Jadilah pemikir yang merdeka agar dapat mengatasi segala bentuk kecurigaan, dan dengan demikian akan dapat mengatasi pemimpin yang zalim dan para penindas yang kejam.

Keenam, Kant mengingatkan kendatipun hidup ini ada batasanbatasan yang diterapkan oleh rezim atau kekuasaan, sesungguhnya kebebasan rasio ini menjadi lentera bagi keberanian untuk berdebat demi sebuah kebenaran.

Ketujuh, Kant percaya bahwa masyarakat harus didorong terus untuk berani menggunakan rasio secara bebas, meskipun suatu pemerintahan atau rezim penguasa akan memberikan batasan yang ketat, ancaman dan pelarangan.

Kedelapan, Kant mengkritisi agama yang dijadikan alat untuk mengekang kebebasan rasio, karena sesungguhnya tidak ada pemikiran rasional yang bertentangan dan kontradiktif dengan ajaran agama, sejauh hal itu didasarkan pada kejujuran dan kewajiban individu untuk patuh terhadap moral dan kewajiban sebagai manusia.

Kesembilan, Kant percaya bahwa kerukunan antar umat beragama dapat tercipta hanya dengan kebebasan rasio masyarakatnya, sehingga tidak mungkin lagi untuk ditunda-tunda atau kembali menjadi bangsa yang penakut, bodoh dan terkekang.

Kesepuluh, Kant tidak dapat menerima arogansi kekuasaan yang melegitimasi pelarangan terhadap kebebasan rasio rakyatnya hanya untuk berpura-pura patuh atau kekhawatiran yang tidak berdasar akan jatuhnya kekuasaan dengan kecerdasan rakyatnya. Sikap beragama yang cerdas sesungguhnya harus berdasarkan pada kebebasan rasio, sebab itulah makna sejati Pencerahan Kant, dan dari sana akan lahir toleransi antar umat beragama.

Kesebelas, Kant mengingatkan bahwa ketidakmatangan dalam beragama akan sangat merugikan sebuah Negara. Apalagi jika penguasa tidak memberikan jaminan kebebasan rakyatnya untuk menggunakan rasio 
mereka. Kepala Negara yang mendukung pencerahan keagamaan akan membuat nasib rakyatnya menjadi lebih baik.

Keduabelas, Kant sangat berharap bahwa pemimpin yang tercerahkan dapat melepaskan dirinya dari bayang-bayang orang lain yang menakutkan dan membelenggunya selama ini. Dampak dari sikap kepemimpinan yang peduli terhadap kebebasan rasio dapat mendorong rakyatnya untuk membangun bangsanya dengan kemampuan sepenuh hati dan menguntungkan bagi semuanya.

\section{Kesimpulan}

Pada prinsipnya, manusia itu harus bebas dan punya kebebasan rasio. Kant percaya bahwa Tuhan memberi manusia kebebasan rasio dalam menjalani dan memaknai kehidupannya. Kebebasan ialah kemampuan untuk diatur oleh budi dan Kant menyebut kemampuan ini sebagai otonomi kehendak. Kant adalah seorang humanis yang percaya pada kemampuan akal budi yang menekankan pada otonomi kehendak sebagai prinsip moralitas tertinggi yang dibedakannya dari heteronomi. Otoritas iman itu sesungguhnya ada di dalam diri kita sendiri tidak berada di luar manusia. Bagi Kant, manusia adalah otoritas terakhir dalam menilai iman.

Jika Kant menekankan yang universal, Hegel (1770-1831) menambahkan dimensi historis dalam filsafat, ia sangat mengagumi dan sebenarnya ingin menyaingi Kant. Saat Kant masih hidup, tepatnya akhir abad ke-18, muncul kubu-kubu yang saling menyerang dalam tradisi filsafat dan lusinan filsuf muda bertarung untuk menjadi penerusnya, seperti Johann Fichte (1762-1814) dan teman kuliahnya Hegel, Friedrich Schelling (1775-1854). Pemikiran filsafat mereka di bawah bayangbayang Kant dan ingin menyempurnakan sistem filsafatnya Kant.

Filsafat baru yang muncul di Jerman ialah Romantisme Jerman yang menolak pemikiran Kant, lebih menekankan pada kolektivitas daripada individual. Aliran ini adalah gerakan revolusioner dalam bidang sastra, filsafat, dan seni visual daripada politik, yang kecewa dan menolak ide pencerahan Kant sebagai suatu filsafat yang didominasi oleh alasan logika, hukum rumusan matematis dan hukum alamiah yang abstrak. Aliran ini bergerak lewat puisi, novel, drama dan kesenian untuk memprotes filsafat yang tak menggubris mereka. Salah satu tokohnya 
ialah Johann Wolfgang von Goethe (1749-1832) yang terkenal dengan karyanya Faust.

Kant mengakui pemikirannya sebagai revolusi Copernikan dalam filsafat karena berhasil mendamaikan perseteruan antara aliran rasionalisme dengan empirisme. Pada abad ke-19 perhatian bagi Kant disebut Kantianisme dan pada abad ke-20 mulai muncul perhatian baru pada Kant dalam aliran neo-kantianisme yang ingin membaca kembali Kant, meneruskan prinsip-prinsip filsafat dan kritisisme Kant-seperti lahirnya fenomenologi. Neo-kantianisme ingin mengatasi cara berpikir positivistik. Para pemikir seperti Lange, Liebmann dan Riehl mengajak kembali kepada ajaran Kant. Pengaruh aliran ini sampai ke Belanda, Italia dan negeri-negeri Skandinavia.

Dalam tradisi kritis, keterkaitan intelektual antara pemikiran Immanuel Kant dengan Hegel, Marx, Nietzsche, Weber, Adorno dan Horkheimer, Husserl, Heidegger, Gadamer, Wittgenstein dan Arendt cukup kuat. Pemikiran Kant juga sangat berpengaruh terhadap para filsuf dan pemikir sesudahnya, para teoretikus dan filsuf kontemporer seperti: Deleuze, Foucault, Lyotard, Habermas dan Rorty banyak dipengaruhi oleh Immanuel Kant. ${ }^{12}$

Pencerahan Inggris dan Prancis hingga pada konsepsi Kant tentang Pencerahan yang menjadi ciri khas Pencerahan dalam filsafat Jerman memberikan landasan moral sekaligus kecerdasan spiritual otentik yang nyala apinya dapat membebaskan rasio manusia modern untuk berani berpikir dan melakukan perubahan yang signifikan bagi masyarakatnya. Bahkan bagi penguasa despotik dan sadis terhadap rakyatnya sendiri dalam menjalankan roda pemerintahan, pesan Kant seolah-olah menjadi ancaman yang nyata bahwa jangan pernah sekali-kali menyakiti rakyatnya dengan membungkan kebebasan rasio mereka, sebab yang demikian itu sangat merugikan dan dapat menyebabkan terjadinya intoleransi dalam sikap keberagamaan dan kebangsaan. Sikap berpura-pura dalam membangun sebuah bangsa yang didasarkan pada pemaksaan kehendak, tenggelam dalam pencitraan dan hilangnya kesadaran untuk bersikap dewasa hanya akan meredupkan lentera kebahagiaan.

Pesan Kant yang tajam secara metafisik sesungguhnya dapat dimaknai lebih dalam tidak hanya mengukuhkan prinsip-prinsip dasar

\footnotetext{
${ }^{12}$ Jon Simons, From Kant to Levi-Strauss, hlm. 3-4.
} 
kebebasan rasio dan keberanian berpikir bagi manusia, tetapi juga secara tersirat menggugat otoritas keagamaan yang seringkali dalam sejarah berselingkuh dengan kekuasaan despotik dalam rangka memuluskan proyek-proyek pembangunan dan penindasan. Tindakan pemimpin yang sewenang-wenang dan agamawan yang bersikap diam atau bahkan menyetujui sikap penguasa yang menyimpang adalah ancaman bagi tatanan moral dan nilai-nilai kemanusiaan. Masyarakat harus didorong agar berani menggunakan rasionya sendiri dengan sepenuhnya, sebab dari sana bermuara kebebasan dan terbitnya kemandirian. Manusia yang membiarkan dirinya tenggelam dalam ketakutan dan terkungkung oleh tekanan kekuasaan dan agama sehingga menyebabkan hilangnya kebebasan rasio, di situlah sebenarnya kritik fundamental Immanuel Kant. 


\section{DAFTAR PUSTAKA}

Fearn, Nicholas. Zeno and the Tortoise: How to Think Like a Philosopher (New York: Grove Press, 2001).

Godechot, Jacques. Revolusi di Dunia Barat (1770-1799), terj. Pusat Kebudayaan Prancis (Yogyakarta: UGM Press, 1989)

Hardiman, F. Budi. Filsafat Modern: Dari Machiavelli sampai Nietzsche (Jakarta: Gramedia, 2004).

Kant, Immanuel. Foundations of the Metaphysics of Morals, terj. Lewis White Beck (Macmillan: Library of Liberal Arts, 1990), dari edisi Jerman, Grundlegung zur Metaphysik der Sitten (1785) dan Beantwortung der Frage: Was ist Aufklärung? (1784).

Lowith, Karl. From Hegel to Nietzsche: The Revolution in NineteenthCentury Thought (New York, Chicago dan San Fransisco: Holt, Rinehart dan Winston, 1965).

Russell, Bertrand. History of Western Philosophy and its Connection with Political and Social Circumstances from the Earliest Times to the Present Day (London: George Allen and UNWIN LTD, 1946)

Simons, Jon (ed.). From Kant to Levi-Strauss: The Background to Contemporary Critical Theory (Edinburg: Edinburg University Press, 2002).

Tjahjadi, S.P.L. Petualangan Intelektual: Konfrontasi dengan Para Filsuf dari Zaman Yunani hingga Zaman Modern (Yogyakarta: Kanisius, 2004)

Wolff, Robert Paul (ed.). Kant: A Collection of Critical Essays (London dan Melbourne: Macmillan, 1968). 